\title{
Persepsi Siswa terhadap Google Classroom sebagai LMS pada masa Pandemi Covid-19
}

\author{
${ }^{1}$ Nelius Harefa, ${ }^{2}$ Sumiyati \\ ${ }^{1}$ Prodi Pendidikan Kimia, FKIP, Universitas Kristen Indonesia, Jakarta \\ Email Korespondensi: nelius.harefa@uki.ac.id
}

\author{
Article Info \\ Article History \\ Received: 08 August 2020 \\ Revised: 31 August 2020 \\ Published: 25 September \\ 2020 \\ Keywords \\ Covid-19; \\ google classroom, \\ LMS
}

\section{Informasi Artikel \\ Sejarah Artikel}

Diterima: 08 Agustus 2020

Direvisi: 31 Agustus 2020

Dipublikasi: 25 September 2020

Kata kunci

Covid-19; google classroom; LMS

\begin{abstract}
Students' perceptions of Google Classroom as an LMS during the Covid-19 Pandemic. The Covid-19 pandemic has an impact on the educational aspect, the learning process has changed from conventional to online learning. One important element of implementing online learning is the availability of an LMS. Google classroom is an LMS that can be used in the online learning process. This LMS is supported by various features that can be elaborated to support the learning process. In this study, students' perceptions were analyzed and interpreted regarding the use of google classrooms in the learning process during the Covid-19 pandemic. The data were collected by providing a research instrument in the form of a questionnaire consisting of 10 statements and completed with 5 answer options for each student. Analysis and interpretation show that $39.19 \%$ feel very excited about the implementation of google classroom in the learning process during the Covid-19 pandemic, $41.89 \%$ of students feel very happy with integrating of google classroom, $47.30 \%$ of students are happy with the acquisition of grades, $41.89 \%$ of students felt that they were not burdened by the assignments has been given by google classroom, $51.35 \%$ felt normal in doing independent assignments given through google classroom, 39.19\% of students feel interested in the implementation of google classroom, $36.49 \%$ are enthusiastic and $40.54 \%$ feel interested in the learning process assisted by google classroom, 56.76\% of students feel that the use of google classroom is ease to use, and $70.27 \%$ of students are understood how to implemented the google classroom in the learning process after being explained by the teacher.
\end{abstract}
Abstrak
Pandemi Covid-19 berpengaruh terhadap aspek pendidikan, proses pembelajaran bergeser dari pembelajaran konvensional (tatap muka) di kelas menjadi pembelajaran online. Salah satu unsur penting dari penerapan pembelajaran online yakni ketersediaan LMS. Google classroom merupakan salah satu LMS yang dapat dimanfaatkan pada proses pembelajaran online. LMS ini didukung berbagai fitur yang dapat dielaborasi untuk mendukung proses pembelajaran. Pada penelitian ini, persepsi siswa dianalisis dan diinterpretasi terhadap pemanfaatan google classroom pada proses pembelajaran selama pandemi Covid-19. Data dikumpulkan dengan memberikan instrumen penelitian berupa angket yang terdiri dari 10 pernyataan dan dilengkapi dengan 5 opsi jawaban kepada masing-masing siswa. Analisis dan interpretasi menunjukkan bahwa 39,19\% merasa sangat bersemangat dengan pengimplementasian google classroom pada proses pembelajaran selama pandemi Covid-19, 41,89\% siswa merasa sangat senang pada proses pembelajaran terintegrasi google classroom, 47,30\% siswa merasa senang akan perolehan nilai selama proses pembelajaran berbantukan google classroom, $41,89 \%$ siswa merasa tidak terbebani akan tugas yang diberikan oleh guru selama proses pembelajaran berbantukan google classroom, 51,35\% merasa biasa saja dalam mengerjakan tugas mandiri yang diberikan melalui google classroom, 39,19\% siswa merasa tertarik terhadap pengimplementasian google classroom sebagai LMS pada proses pembelajaran, 36,49\% merasa antusias 
pada proses pembelajaran berbantukan google classroom, 40,54\% merasa tertarik pada proses pembelajaran berbantukan google classroom, 56,76\% siswa beranggapan bahwa pemanfaatan google classroom pada proses pembelajaran pada kategori mudah, dan 70,27\% siswa memahami cara pengimplementasian google classroom pada proses pembelajaran setelah dijelaskan oleh guru.

Sitasi: Harefa, Nelius \& Sumiyati. (2020). Persepsi Siswa terhadap Google Classroom sebagai LMS pada masa Pandemi Covid-19. Science Education and Application Journal. 2(2) 88-100.

\section{PENDAHULUAN}

Pandemi Covid-19 mempengaruhi tatanan sektor kehidupan, salah satunya sektor pendidikan. Penerapan pembelajaran online menjadi solusi alternatif untuk mengakomodasi proses pembelajaran dalam upaya pencegahan penyebaran Covid-19. Aplikasi-aplikasi online dimanfaatkan secara masif untuk mendukung keberlanjutan proses pembelajaran. Pengimplementasian media-media online seperti multimedia (Harefa, dkk., 2020), schoology (Sugiarto, 2020), dan exe-media (Harefa and Suyanti, 2019), serta media-media online lainnya (Cakrawati, 2017), (Septaria and Dewanti, 2019), (Mustakim, 2020) menjadi solusi ideal selama pandemi Covid-19.

Media pembelajaran lain yang telah banyak diterapkan pada proses pembelajaran yakni google classroom. Google classroom merupakan aplikasi yang dapat mendukung proses mengajar dan pembelajaran (Mohd. Shaharanee, et al., 2016). Aplikasi ini sering digunakan sebagai pendukung pada proses pembelajaran konvensional, blended, maupun online (Hapsari and Pamungkas, 2019), (Nurfalah, 2019), (Zurimi, 2019). Selain itu, google classroom merupakan salah satu aplikasi yang dapat digunakan sebagai Learning Management System (LMS) dan bersifat fleksibel, aplikasi ini dapat diimplementasikan pada materi saintik, sochum, dan materi-materi pembelajaran yang terkait dengan teknologi informasi dan komunikasi (Hapsari, 2019), (Muslik, 2019), (Tumengkol, 2020). Aplikasi ini memiliki berbagai fitur dan fasilitas yang dapat dimanfaatkan untuk mendukung proses pembelajaran jarak jauh (Putri and Dewi, 2019), (Harefa, 2020).

Secara umum, google classroom dapat mempengaruhi proses pembelajaran dari berbagai aspek, baik aspek kognitif, afektif, maupun psikomotorik. Azhar and Iqbal (2018), melalui penelitiannya mengungkapkan bahwa mayoritas guru beranggapan bahwa google classroom merupakan salah satu media pembelajaran yang sangat efektif apabila diterapkan pada proses pembelajaran. Melalui penerapan google classroom, proses pembelajaran dan ditingkatkan menjadi lebih interaktif serta memfasilitasi siswa dalam upaya peningkatan keterampilan (Nazari, et al., 2019). Sementara itu, melalui penerapan google classroom, proses pembelajaran dapat berlangsung lebih efektif (Basher, 2017), (Sudarsana, et al., 2019) dan efisien (Harefa and Purba, 2020). Kompetensi lain yang dapat ditingkatkan melalui penerapan google classroom yakni kedisiplinan, kedisplinan peserta kelas dapat ditingkatkan secara signifikan, ketepatan waktu yang dapat diatur secara otomatis menstimulus siswa untuk meningkatkan kedisiplinan (Iftakhar, 2016). Kelas yang lebih dinamis dapat dielaborasi melalui penerapan google classroom, dan partisipasi siswa dapat ditingkatkan secara signifikan (Heggart and Yoo, 2018).

Pengimplementasian google classroom yang fleksibel dan sederhana (Harefa, 2020) memudahkan siswa dalam mengelaborasi setiap fitur untuk menunjang proses pengembangan kompetensi. Hasil belajar dan respon motivasi dapat ditingkatkan melalui penerapannya (Sudibjo, 2019), (Batita, dkk., 2019). Keterampilan berfikir kreatif dan kemandirian belajar dapat dielaborasi dengan optimal melalui pengimplementasian google classroom (Haka, dkk., 
2020). Selain itu, google classroom merupakan LMS fleksibel yang dapat dikolaborasikan dengan media pembelajaran, metode pembelajaran, model pembelajaran, dan strategi pembelajaran. Pengintegrasian google classroom dengan PLS-SEM dapat meningkatkan minat belajar siswa secara signifikan (Al-Maroof, 2018). Pengintegrasian google classroom dengan metode pembelajaran kolaborasi dapat meningkatkan nilai karakter siswa (Maesaroh, dkk., 2019).

Kendati demikian, perlu dilakukan analisis dan evaluasi secara berkala terkait penerapan google classroom, sehingga pengimplementasiannya lebih optimal serta dapat diimplementasi secara menyeluruh dan utuh. Salah satu indikator yang penting untuk dianalisis yakni persepsi siswa terhadap pengimplementasiannya. Persepsi siswa merupakan indikator penting yang erat kaitannya dengan proses pembelajaran. Persepsi siswa sangat erat kaitannya dengan hasil belajar (Najichun and Winarso, 2017), (Marhent, 2015), (Saputra and Syafik, 2016), siswa yang memiliki persepsi yang baik umumnya akan mengoptimalkan proses belajar mandiri yang dapat meningkatkan hasil belajarnya. Selain itu, persepsi dapat mempengaruhi minat siswa dalam menentukan suatu pilihan (Wardana, dkk., 2018) dan prestasi akademik (Remali, et al., 2015).

Oleh sebab itu, perlu diperhatikan bahwa persepsi siswa merupakan indikator yang sangat dinamis. Persepsi siswa dapat dipengaruhi oleh beberapa indikator, salah satunya penerapan metode pembelajaran yang berbeda-beda (Riedy, et al., 2012). Perlu diperhatikan bahwa setiap metode, media, model, dan strategi pembelajaran memiliki karakteristik yang berbeda, oleh sebab itu pengimplementasian google classroom perlu disesuaikan dengan karakteristik-karakteristik tersebut sehingga proses pembelajaran dapat efektif dan efisien. Selain itu, keterpahaman akan tools suatu media atau LMS dapat mempengaruhi persepsi siswa (Portnov-Neeman and Barak, 2015).

\section{METODE}

Penelitian ini dilakukan di SMA Abdi Siswa Bintaro Tangerang pada Maret - Mei 2020. Pengumpulan data dilakukan setelah proses pembelajaran kimia berbantukan google classroom pada materi kimia kelas X IPA dan XI IPA yang berjumlah 74 orang. Instrumen pengumpulan data yakni angket yang telah valid dan diberikan kepada masing-masing siswa. Angket terdiri dari 10 pernyataan, masing-masing pernyataan diberi 5 opsi jawaban. Data angket diolah, dianalisis, dan diinterpretasi berbantukan Microsoft Excel for windows. Instrumen penelitian seperti pada Tabel 1.

Tabel 1. Instrumen Penelitian

\begin{tabular}{|c|c|c|c|c|c|c|}
\hline \multirow{2}{*}{ No } & \multirow{2}{*}{ Pernyataan } & \multicolumn{5}{|c|}{ Opsi } \\
\hline & & $\mathrm{A}$ & B & C & D & $E$ \\
\hline 1. & $\begin{array}{l}\text { Saya bersemangat setiap mengikuti } \\
\text { proses pembelajaran terintegrasi } \\
\text { google classroom selama pandemi } \\
\text { Covid-19 }\end{array}$ & $\begin{array}{l}\text { Sangat } \\
\text { berseman } \\
\text { gat }\end{array}$ & $\begin{array}{l}\text { Berseman } \\
\text { gat }\end{array}$ & Netral & $\begin{array}{l}\text { Tidak } \\
\text { bersema } \\
\text { ngat }\end{array}$ & $\begin{array}{l}\text { Sangat } \\
\text { tidak } \\
\text { berseman } \\
\text { gat }\end{array}$ \\
\hline 2. & $\begin{array}{l}\text { Saya senang mengikuti proses } \\
\text { pembelajaran terintegrasi google } \\
\text { classroom selama pandemi Covid-19 }\end{array}$ & $\begin{array}{l}\text { Sangat } \\
\text { senang }\end{array}$ & Senang & Netral & $\begin{array}{l}\text { Tidak } \\
\text { senang }\end{array}$ & $\begin{array}{l}\text { Sangat } \\
\text { tidak } \\
\text { senang }\end{array}$ \\
\hline 3. & $\begin{array}{l}\text { Saya senang apabila mendapatkan } \\
\text { nilai tugas yang baik melalui belajar } \\
\text { mandiri terintegrasi google classroom } \\
\text { selama pandemi Covid-19 }\end{array}$ & $\begin{array}{l}\text { Sangat } \\
\text { senang }\end{array}$ & Senang & Netral & $\begin{array}{l}\text { Tidak } \\
\text { senang }\end{array}$ & $\begin{array}{l}\text { Sangat } \\
\text { tidak } \\
\text { senang }\end{array}$ \\
\hline 4. & $\begin{array}{l}\text { Saya merasa terbebani mengerjakan } \\
\text { tugas yang diberikan guru melalui }\end{array}$ & $\begin{array}{l}\text { Sangat } \\
\text { terbebani }\end{array}$ & Terbebani & Netral & $\begin{array}{l}\text { Tidak } \\
\text { terbeban }\end{array}$ & $\begin{array}{l}\text { Sangat } \\
\text { tidak }\end{array}$ \\
\hline
\end{tabular}


google classroom selama pandemi Covid-19

5. Saya senang mengerjakan tugas secara mandiri melalui google classroom selama pandemi Covid-19

6. Saya tertarik terhadap penggunaan google classroom pada proses pembelajaran selama pandemi Covid19

7. Saya antusias jika guru memberikan pertanyaan melalui google classroom pada proses pembelajaran selama pandemi Covid-19

8. Google classroom sangat menarik jika diterapkan pada proses pembelajaran karena menyediakan fitur-fitur yang beragam dan menarik

9. Saya kesulitan menggunakan/mengimplementasikan google classroom pada proses pembelajaran selama pandemi Covid19

10. Saya memahami penggunaan fiturfitur google classroom pada proses pembelajaran selama pandemi Covid19

\begin{tabular}{|c|c|c|c|c|}
\hline $\begin{array}{l}\text { Sangat } \\
\text { senang }\end{array}$ & Senang & Netral & $\begin{array}{l}\text { Tidak } \\
\text { senang }\end{array}$ & $\begin{array}{l}\text { Sangat } \\
\text { tidak } \\
\text { senang }\end{array}$ \\
\hline $\begin{array}{l}\text { Sangat } \\
\text { tertarik }\end{array}$ & Tertarik & Netral & $\begin{array}{l}\text { Tidak } \\
\text { tertarik }\end{array}$ & $\begin{array}{l}\text { Sangat } \\
\text { tidak } \\
\text { tertarik }\end{array}$ \\
\hline $\begin{array}{l}\text { Sangat } \\
\text { antusias }\end{array}$ & Antusias & Netral & $\begin{array}{l}\text { Tidak } \\
\text { antusias }\end{array}$ & $\begin{array}{l}\text { Sangat } \\
\text { tidak } \\
\text { antusias }\end{array}$ \\
\hline $\begin{array}{l}\text { Sangat } \\
\text { menarik }\end{array}$ & Menarik & Netral & $\begin{array}{l}\text { Kurang } \\
\text { menarik }\end{array}$ & $\begin{array}{l}\text { Tidak } \\
\text { menarik }\end{array}$ \\
\hline $\begin{array}{l}\text { Sangat } \\
\text { kesulitan }\end{array}$ & Kesulitan & Netral & Mudah & $\begin{array}{l}\text { Sangat } \\
\text { mudah }\end{array}$ \\
\hline $\begin{array}{l}\text { Memaha } \\
\text { mi } \\
\text { seluruhny } \\
\text { a }\end{array}$ & $\begin{array}{l}\text { Memaha } \\
\text { mi } \\
\text { sebagian }\end{array}$ & $\begin{array}{l}\text { Memaha } \\
\text { mi } \\
\text { setelah } \\
\text { dijelask } \\
\text { an guru }\end{array}$ & $\begin{array}{l}\text { Memaha } \\
\text { mi } \\
\text { setelah } \\
\text { mempel } \\
\text { ajarinya } \\
\text { sendiri }\end{array}$ & $\begin{array}{l}\text { Tidak } \\
\text { memaha } \\
\text { mi }\end{array}$ \\
\hline
\end{tabular}

terbebani

Pada penelitian ini diperoleh data persepsi siswa terhadap pemanfaatan google classroom pada proses pembelajaran kimia selama pandemi Covid-19. Data tersebut diinterpretasi dan dianalisis sehingga diperoleh gambaran persepsi siswa yang dapat dimanfaatkan sebagai bahan evaluasi pengimplementasiannya.

\section{HASIL DAN PEMBAHASAN}

Instrumen pengumpulan data penelitian yakni angket yang terdiri 10 pernyataan disertai 5 opsi jawaban. Instrumen penelitian diberikan kepada masing-masing siswa setelah pemanfaatan google classroom sebagai LMS pada proses pembelajaran kimia selama pandemi Covid-19. Setiap item instrumen dianalisis dan diinterpretasi untuk mengetahui persepsi siswa.

Stimulus semangat siswa terhadap proses pembelajaran melalui pengimplementasian google classroom seperti pada Gambar 1. 


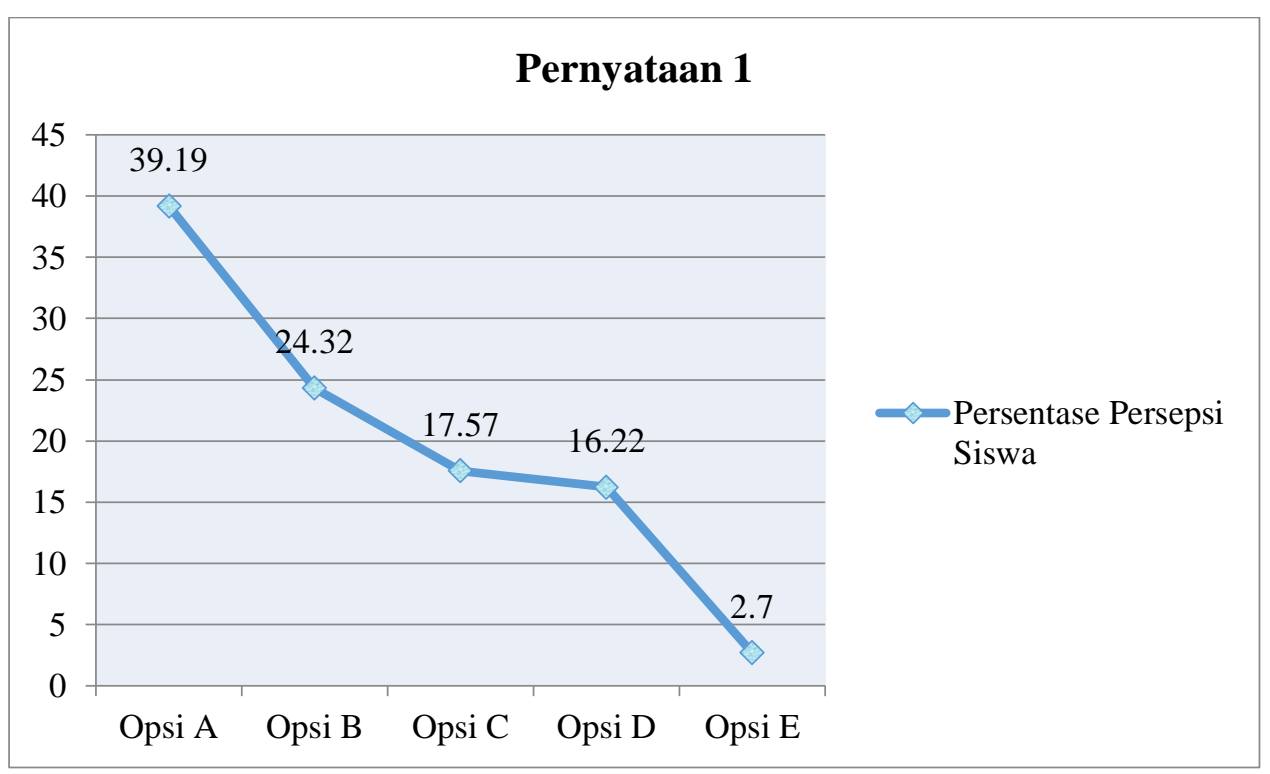

Gambar 1. Rasa Semangat Siswa pada Pengimplementasian Google Classroom

Berdasarkan gambar 1, mayoritas siswa merasa sangat bersemangat dengan pengimplementasian google classroom sebagai LMS proses pembelajaran kimia. Siswa beranggapan bahwa google classroom memberi sensasi baru terhadap proses pembelajaran terutama pada segi proses pemanfaatannya. Namun, terdapat $2,7 \%$ siswa yang beranggapan sangat tidak bersemangat pada proses pembelajaran. Perubahan sistem pembelajaran konvensional menjadi terintegrasi google classroom mengindikasikan siswa menginginkan interaksi sosial yang biasa terjadi pada proses pembelajaran konvensional. Selain rasa semangat, siswa memiliki persepsi terhadap pengimplementasian google classroom pada proses pembelajaran seperti pada Gambar 2.

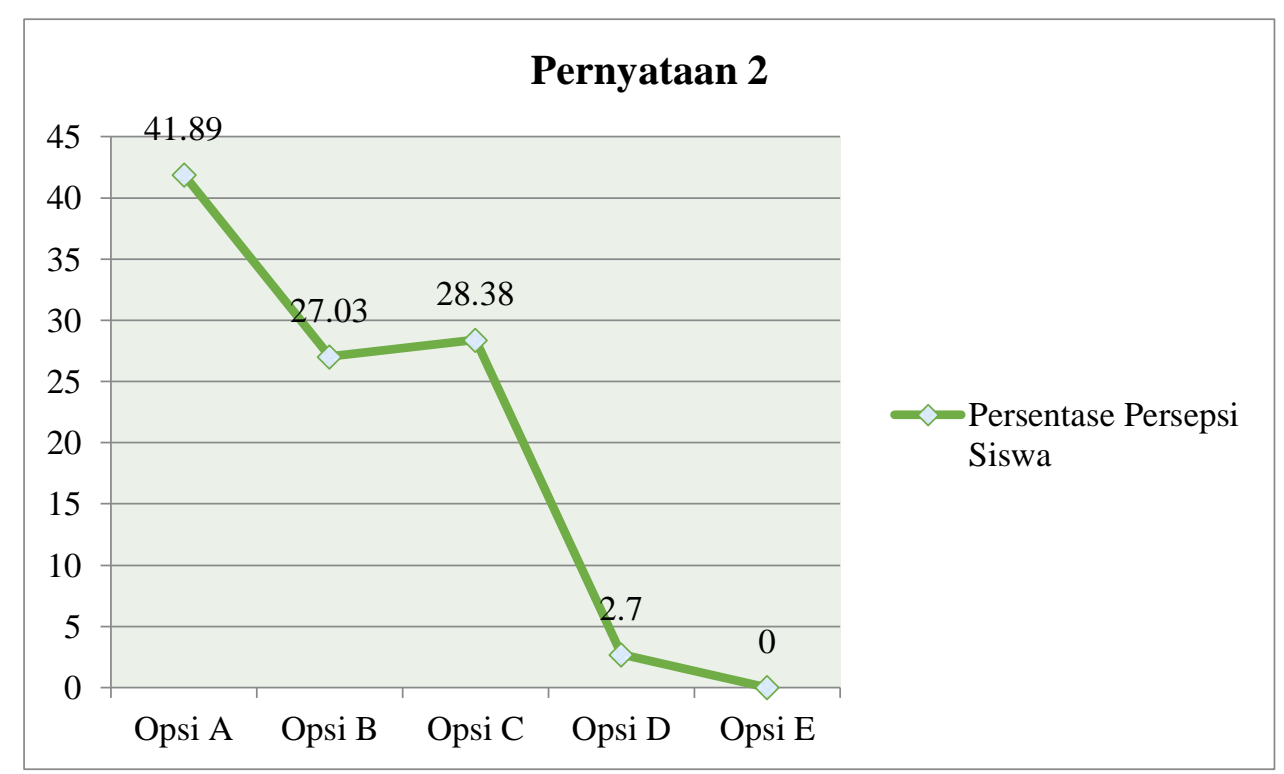

Gambar 2. Perasaan Senang Siswa Mengikuti Proses Pembelajaran

Berdasarkan Gambar 2, 41,89\% siswa merasa sangat senang mengikuti proses pembelajaran berbantukan google classroom. 28,38\% siswa merasa biasa saja (netral), $27,03 \%$ merasa senang, dan 2,7\% merasa tidak senang pada proses pembelajaran berbantukan google classroom. Perubahan tatanan proses pembelajaran selama pandemi Covid-19 berpengaruh terhadap antusiasme siswa dalam mengikuti proses pembelajaran. Selain 
perasaan senang pada proses pembelajaran, siswa memiliki persepsi terhadap perolehan nilai seperti pada Gambar 3.

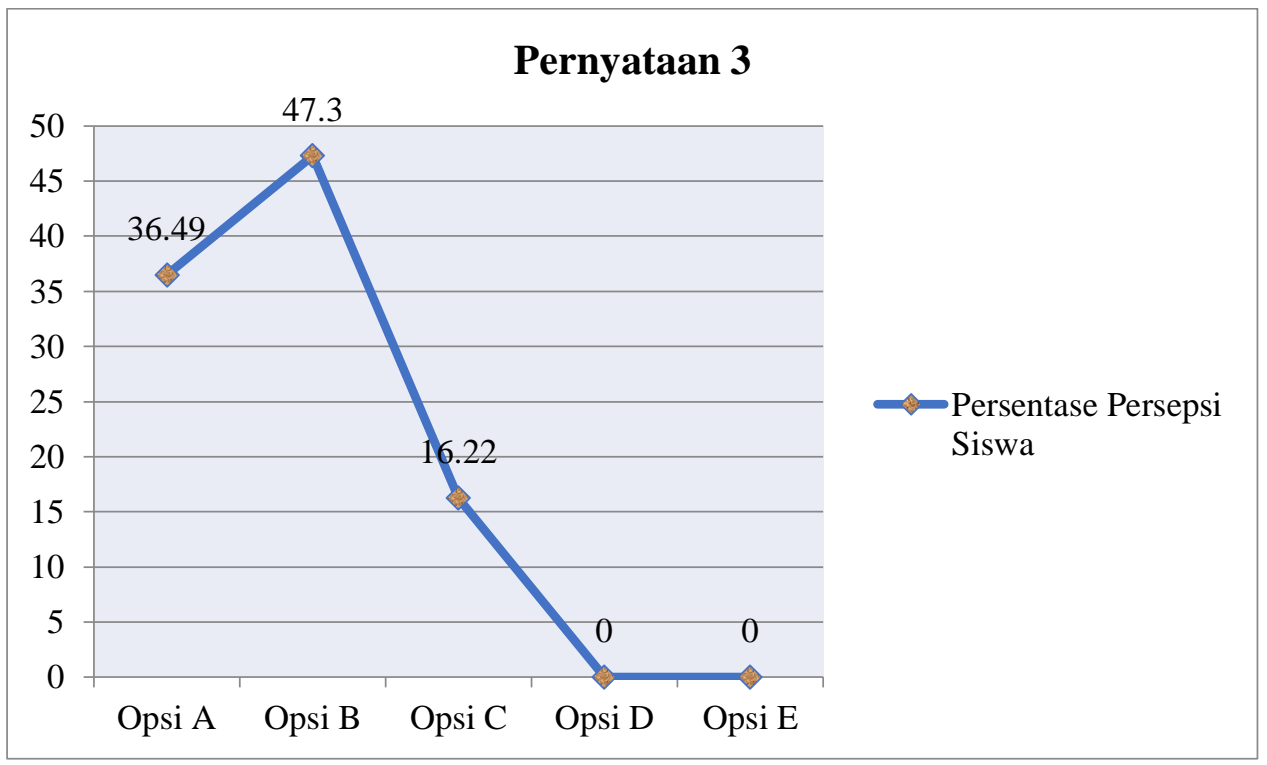

Gambar 3. Perasaan Senang Siswa Terhadap Perolehan Nilai

Berdasarkan Gambar 3, 47,30\% siswa merasa senang akan perolehan nilai selama proses pembelajaran berbantukan google classroom. 36,49\% merasa sangat senang dan $16,22 \%$ merasa biasa saja. Perubahan tatanan penilaian, dimana penilaian berbantukan google classroom akan diupdate secara berkala, transparan, dan dapat diakses oleh seluruh siswa dapat mempengaruhi persepsi siswa terhadap sistem penilaian dan evaluasi pembelajaran. Mayoritas siswa merasa tidak keberatan dengan sistem penilaian demikian, namun sebagian merasa bahwa sistem penilaian merupakan privasi masing-masing siswa. Selain persepsi terhadap perolehan nilai, siswa memiliki persepsi terhadap sistem penugasan seperti pada Gambar 4.

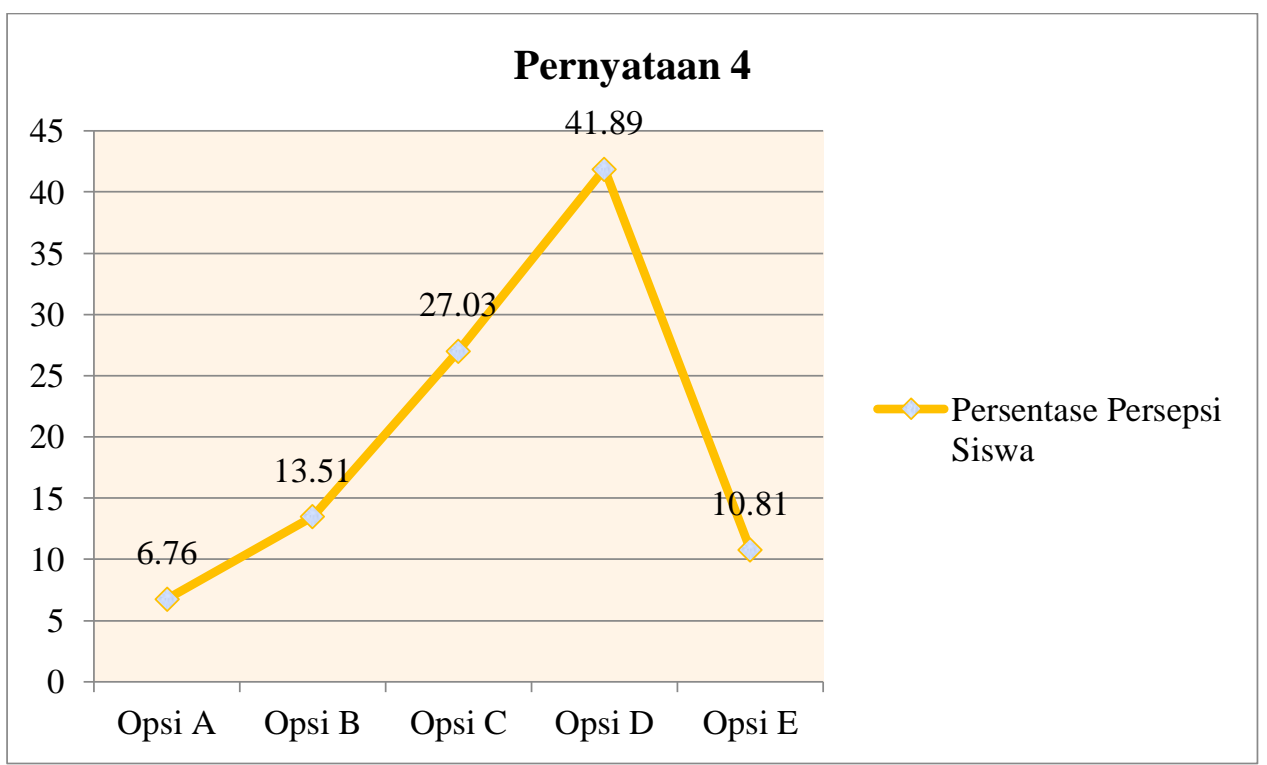

Gambar 4. Perasaan Terbebani Terhadap Tugas

Berdasarkan Gambar 4, 41,89\% siswa merasa tidak terbebani akan tugas yang diberikan oleh guru selama proses pembelajaran berbantukan google classroom. 27,03\% beranggapan biasa saja, 13,51\% beranggapan terbebani, 10,81\% beranggapan sangat tidak 
terbebani, dan $6,76 \%$ merasa sangat terbebani. Perbedaan dalam menjelaskan dan mendiskusikan sistem penugasan pada proses pembelajaran tatap muka dengan pembelajaran berbasis google classroom mempengaruhi persepsi siswa terhadap penugasan. Penjelasan dan pendiskusian tugas pada proses pembelajaran tatap muka cenderung lebih tuntas dibanding pada proses pembelajaran berbasis google classroom, hal ini terindikasi bahwa siswa merasa sangat terbebani akan penugasan pada proses pembelajaran berbasis google classroom. Sementara itu, proporsi penugasan cenderung berkurang pada proses pembelajaran berbantukan google classroom, hal ini terindikasi bahwa siswa cenderung tidak terbebani akan penugasan yang telah disepakati. Selain persepsi akan penugasan, siswa memiliki persepsi beragam akan proses pengerjaan tugas mandiri seperti pada Gambar 5 .

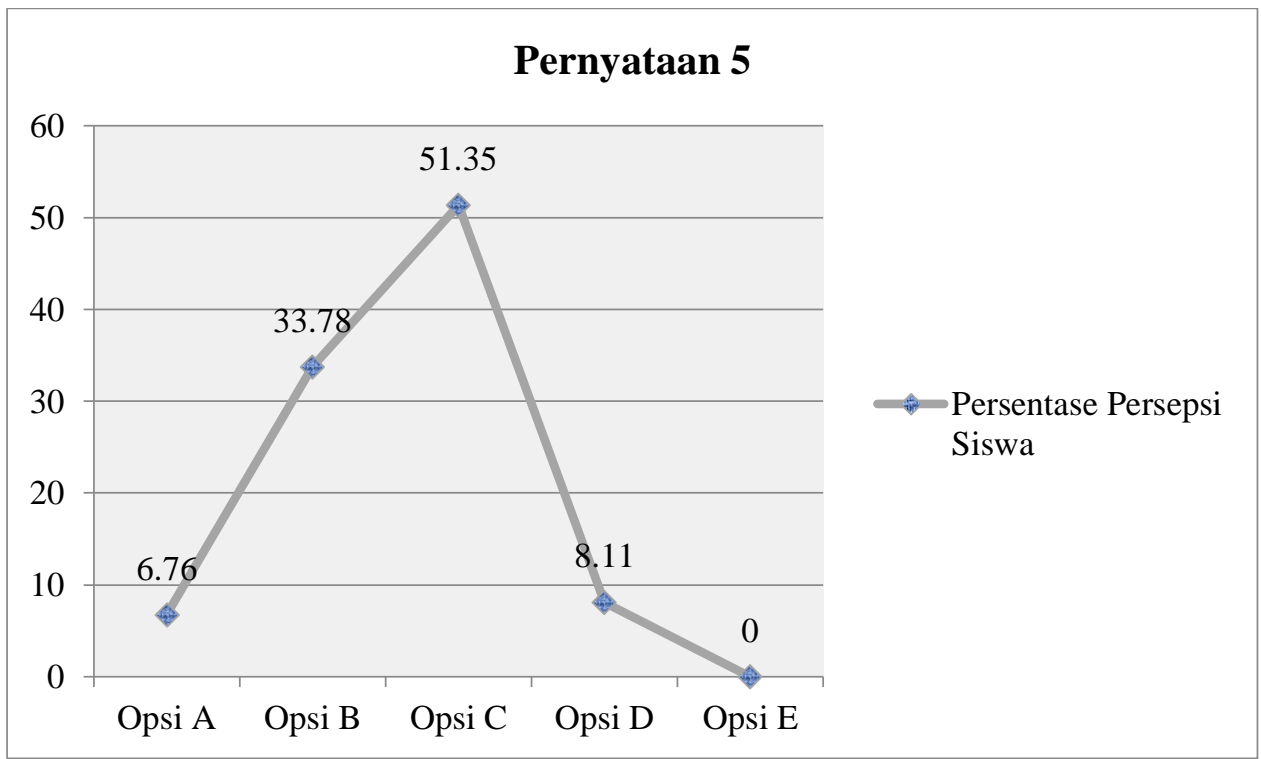

Gambar 5. Perasaan Senang Mengerjakan Tugas Mandiri

Berdasarkan Gambar 5, 6,76\% siswa merasa sangat senang mengerjakan tugas mandiri yang diberikan melalui LMS google classroom. 33,78\% merasa senang, 51,35\% merasa biasa saja, dan $8,11 \%$ merasa tidak senang. Berbagai fitur yang tersedia pada google classroom memungkinkan siswa untuk memanfaatkannya pada proses pengerjaan tugas mandiri, fiturfitur tersebut menyediakan berbagai fasilitas yang dapat memudahkan siswa dalam mengelaborasi setiap penugasan yang diberikan. Sementara itu, kebiasaan siswa yang cenderung menyukai diskusi tatap muka mempengaruhi persepsi mereka terhadap pengerjaan tugas mandiri, siswa cenderung kesulitan pada pengerjaannya mengingat diskusi tatap muka tidak dapat diakomodasi. Selain persepsi terhadap tugas mandiri, siswa memiliki persepsi ketertarikan terhadap google classroom seperti pada Gambar 6. 


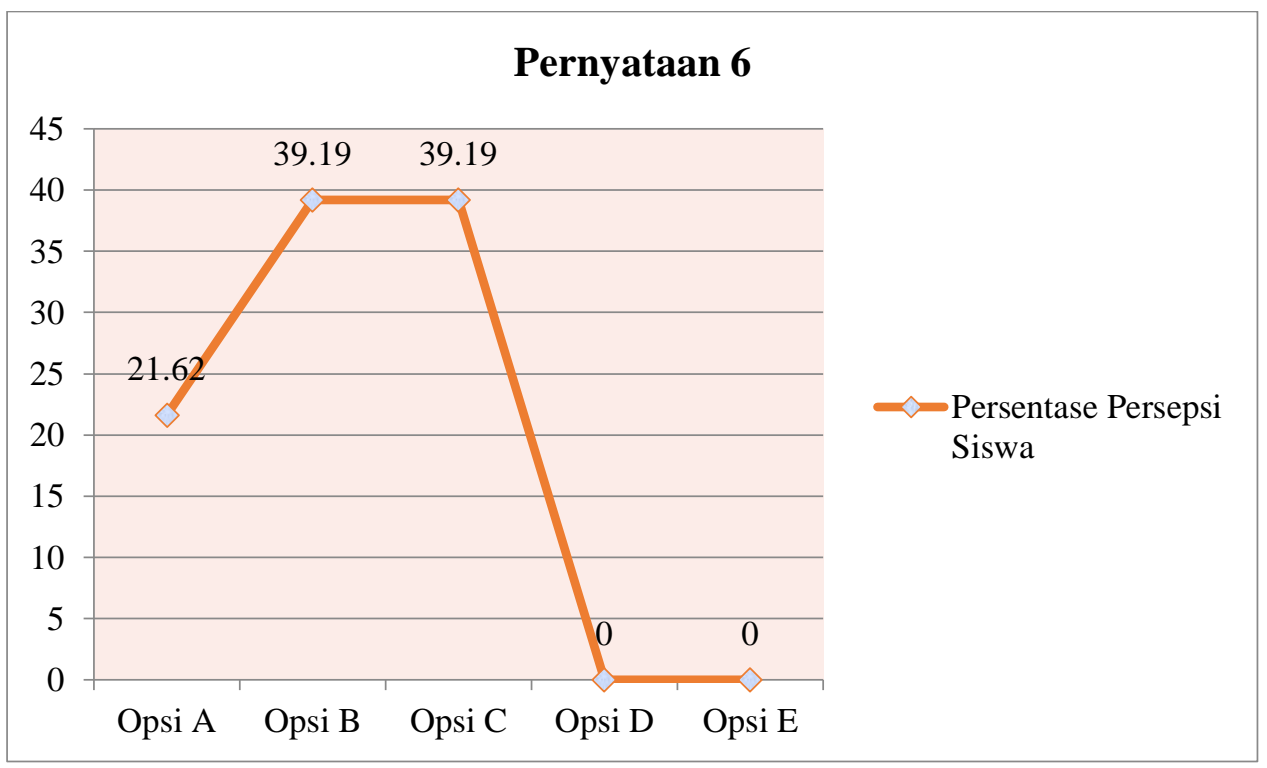

Gambar 6. Perasaan Ketertarikan Terhadap Google Classroom

Berdasarkan Gambar 6, 39,19\% siswa merasa tertarik terhadap pengimplementasian google classroom sebagai LMS pada proses pembelajaran. 39,19\% merasa biasa saja dan $21,62 \%$ merasa sangat tertarik. Ketersediaan berbagai fitur pada google classroom memberikan tantangan kepada siswa untuk meningkatkan pengetahuannya secara mandiri dan menstimulus keingintahuan siswa. Sebaliknya, berkurangnya interaksi sosial secara langsung menyebabkan siswa memiliki persepsi yang kurang baik terhadap pemanfaatan google classroom. Selain perasaan ketertarikan, siswa memiliki persepsi terhadap proses pembelajaran terintegrasi google classroom seperti antusiasme yang ditunjukkan pada Gambar 7.

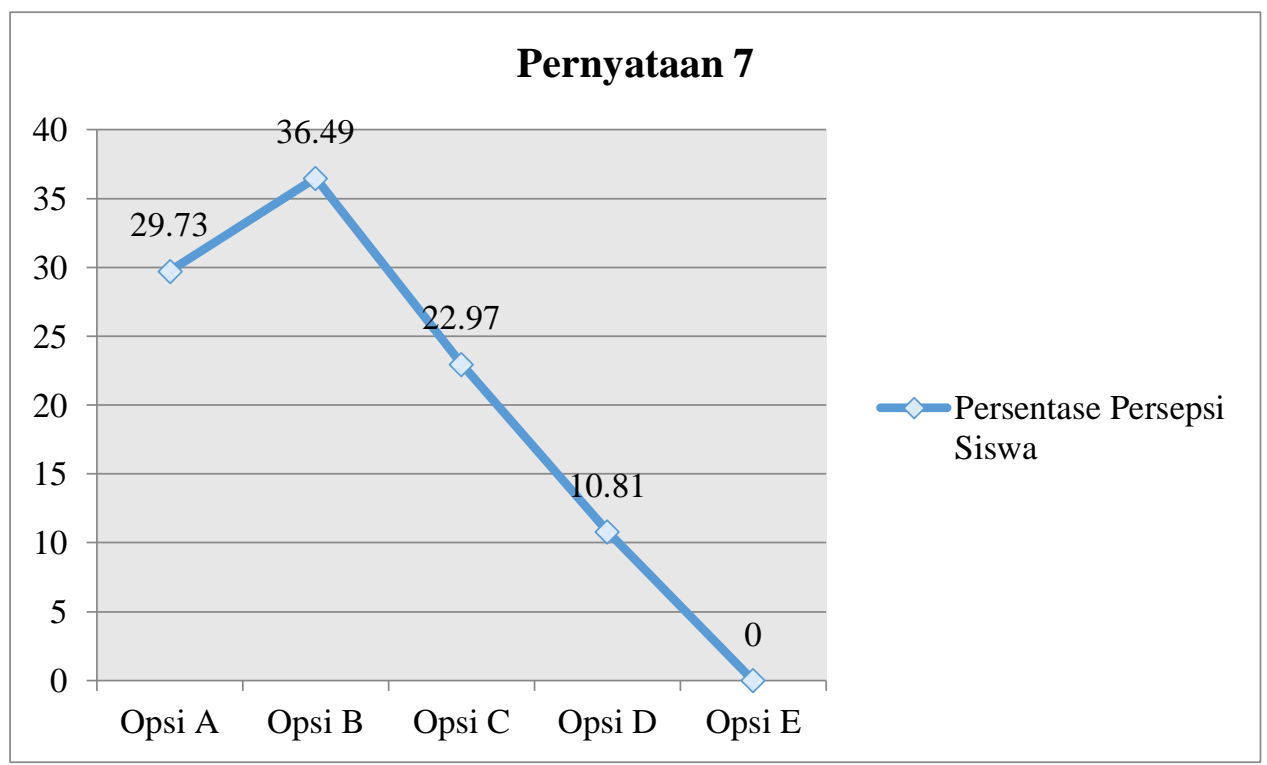

Gambar 7. Antusiasme Siswa Terhadap Proses Pembelajaran

Berdasarkan Gambar 7, 36,49\% merasa antusias pada proses pembelajaran berbantukan google classroom. 29,73\% siswa merasa sangat antusias, 22,97\% merasa biasa saja, dan $10,81 \%$ merasa tidak antusias. Pemberian stimulus pembelajaran seperti pemberian kuis interaktif diawal proses pembelajaran dapat meningkatkan rasa antusias siswa terhadap proses pembelajaran tersebut. Pengimplementasian LMS online berupa aplikasi maupun 
software sangat mendukung dan memfasilitasi kegiatan pembelajaran berupa kuis interaktif. Kendati demikian, kesiapan yang kurang maksimal akibat pandemi Covid-19 menyebabkan google classroom belum dielaborasi dengan utuh sehingga berpengaruh terhadap rasa antusiasme beberapa siswa. Selain antusiasme, siswa memiliki persepsi terhadap rasa ketertarikan pada proses pembelajaran berbantukan google classroom seperti pada Gambar 8 .

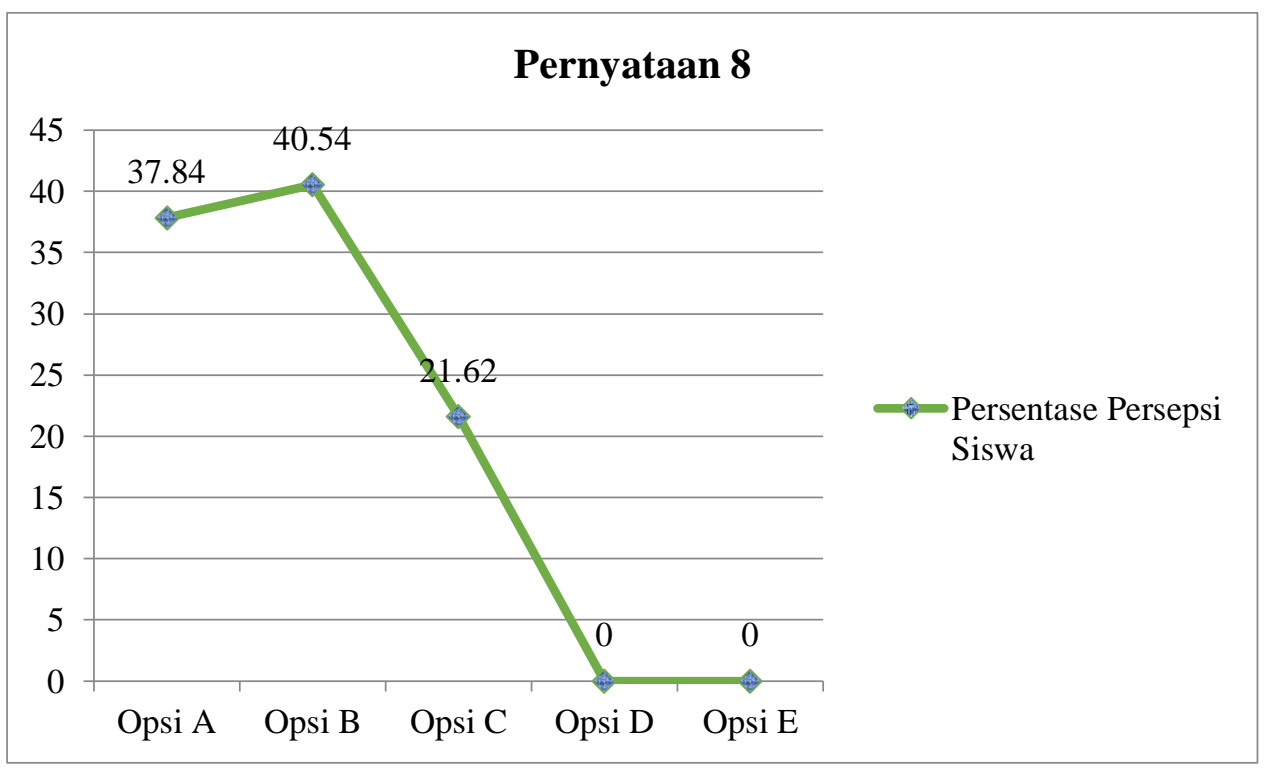

Gambar 8. Ketertarikan Siswa Terhadap Fitur Google Classroom

Berdasarkan Gambar 8, 40,54\% merasa tertarik pada proses pembelajaran berbantukan google classroom. 37,84\% sangat tertarik dan 21,62 merasa biasa saja. Pengimplementasian google classroom memungkinkan guru untuk mengkreasikan bentuk materi dan sistem pembelajaran yang fleksibel. Dengan kreasi-kreasi tersebut, siswa merasa bahwa pembelajaran tidak monoton dan sangat bervariasi. Variasi-variasi tersebut menstimulus ketertarikan siswa terhadap proses pembelajaran, sehingga keingintahuan siswa dapat terstimulus dengan optimal. Selain rasa ketertarikan tersebut, siswa memiliki persepsi terhadap proses pengimplementasian google classroom seperti pada Gambar 9.

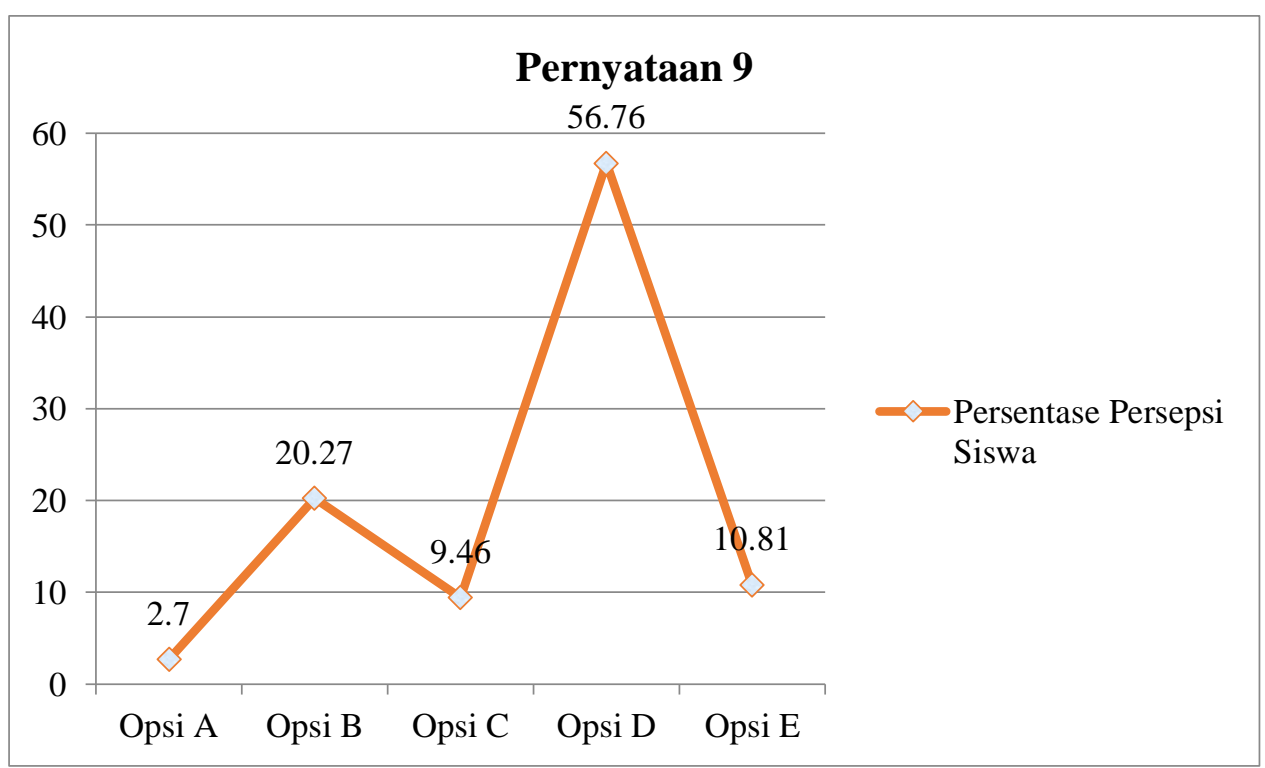

Gambar 9. Kemudahan Pemanfaatan Google Classroom 
Berdasarkan Gambar 9, 56,76\% siswa beranggapan bahwa pengimplementasian google classroom pada proses pembelajaran pada kategori mudah. 20,27\% beranggapan sulit, $10,81 \%$ beranggapan sangat mudah, $9,46 \%$ beranggapan biasa saja, dan $2,7 \%$ beranggapan sangat sulit. Kemudahan pengoperasian suatu LMS berpengaruh terhadap proses pengimplementasiannya pada proses pembelajaran. Kendati kemudahan tersebut bersifat relatif, namun penting bagi guru untuk mencermati dan mengevaluasi pengimplementasian LMS tersebut secara berkala, sehingga luaran proses pembelajaran dapat tercapai.

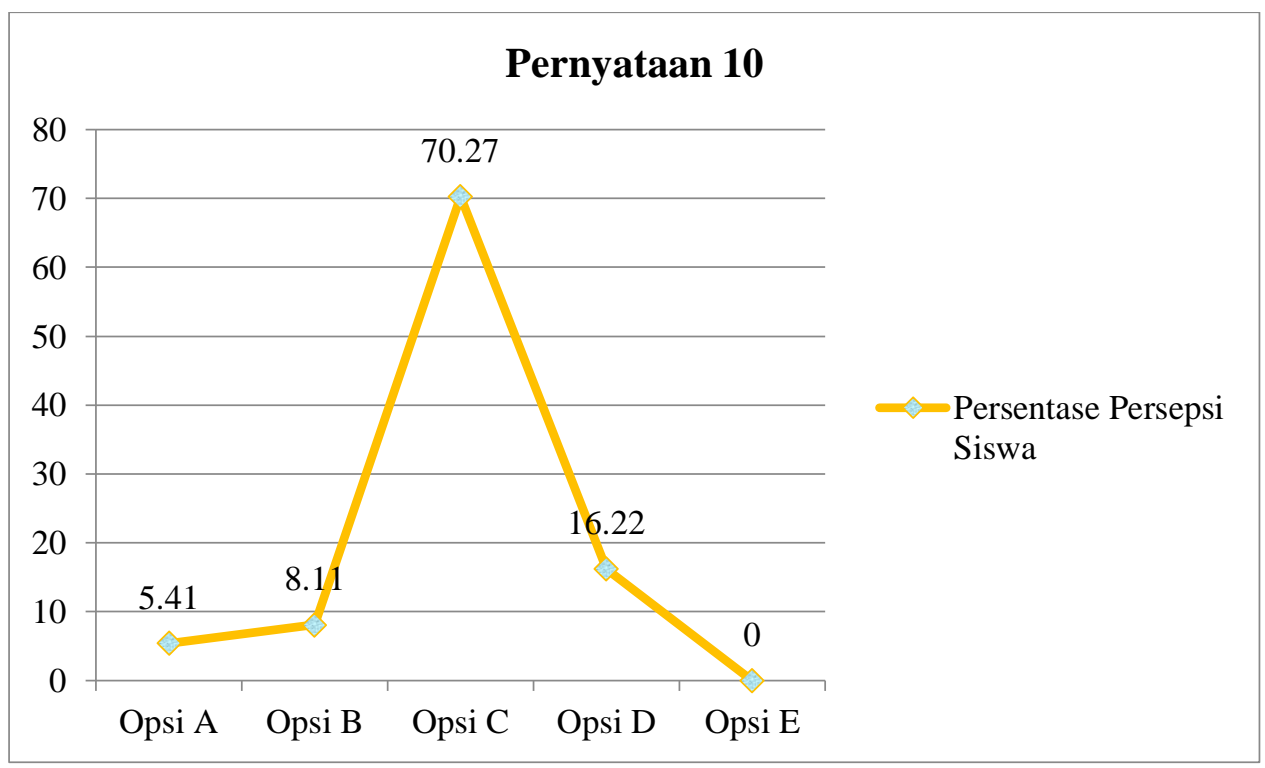

Gambar 10. Keterpahaman Terhadap Pengimplementasian Fitur Google Classroom

Berdasarkan Gambar 10, 70,27\% siswa memahami cara pengimplementasian google classroom pada proses pembelajaran setelah dijelaskan oleh guru. 16,22\% siswa memahami setelah mempelajarinya secara mandiri, $8,11 \%$ siswa memahami penggunaan google classroom sebagian, dan 5,41\% memahami seluruh pengimplementasian google classroom. Data tersebut menunjukkan bahwa peran guru sangat signifikan dan dibutuhkan oleh siswa. Kendati terjadi pergeseran sistem pembelajaran, guru masih harus berperan besar pada prose pembelajaran. Dengan demikian, guru harus mengasah diri dan terbuka akan perkembangan teknologi serta pengimplementasiannya. Selain itu, kreativitas siswa yang tinggi dan mengalami peningkatan seiring penerapan LMS online pada proses pembelajaran mengharuskan guru untuk memahami sebuah LMS yang diterapkan secara menyeluruh.

Persepsi siswa merupakan indikator penting yang erat kaitannya dengan proses pembelajaran. Persepsi siswa sangat erat kaitannya dengan hasil belajar (Najichun and Winarso, 2017), (Marhent, 2015), (Saputra and Syafik, 2016), siswa yang memiliki persepsi yang baik umumnya akan mengoptimalkan proses belajar mandiri yang dapat meningkatkan hasil belajarnya. Selain itu, persepsi dapat mempengaruhi minat siswa dalam menentukan suatu pilihan (Wardana, dkk., 2018) dan prestasi akademik (Remali, et al., 2015). Oleh sebab itu, perlu diperhatikan bahwa persepsi siswa merupakan indikator yang sangat dinamis. Persepsi siswa dapat dipengaruhi oleh beberapa indikator, salah satunya penerapan metode pembelajaran yang berbeda-beda (Riedy, et al., 2012). Perlu diperhatikan bahwa setiap metode, media, model, dan strategi pembelajaran memiliki karakteristik yang berbeda, oleh sebab itu pengimplementasian google classroom perlu disesuaikan dengan karakteristikkarakteristik tersebut sehingga proses pembelajaran dapat efektif dan efisien. Selain itu, keterpahaman akan tools suatu media atau LMS dapat mempengaruhi persepsi siswa (Portnov-Neeman and Barak, 2015). 


\section{KESIMPULAN}

Google classroom merupakan LMS berbasis aplikasi yang dapat dimanfaatkan sebagai platform manajemen pembelajaran online. Aplikasi ini dilengkapi berbagai fitur yang dapat dimanfaatkan sebagai fasilitas pendukung proses pembelajaran. Pada pengimplementasiannya, aplikasi ini memiliki kelebihan maupun kekurangan yang dapat mempengaruhi persepsi siswa terhadap pemanfaatannya. Berdasarkan analisis dan interpretasi data penelitian, 39,19\% merasa sangat bersemangat dengan pengimplementasian google classroom pada proses pembelajaran selama pandemi Covid-19, 41,89\% siswa merasa sangat senang pada proses pembelajaran terintegrasi google classroom, 47,30\% siswa merasa senang akan perolehan nilai selama proses pembelajaran berbantukan google classroom, $41,89 \%$ siswa merasa tidak terbebani akan tugas yang diberikan oleh guru selama proses pembelajaran berbantukan google classroom, 51,35\% merasa biasa saja dalam mengerjakan tugas mandiri yang diberikan melalui LMS google classroom, 39,19\% siswa merasa tertarik terhadap pengimplementasian google classroom sebagai LMS pada proses pembelajaran, $36,49 \%$ merasa antusias pada proses pembelajaran berbantukan google classroom, 40,54\% merasa tertarik pada proses pembelajaran berbantukan google classroom, 56,76\% siswa beranggapan bahwa pengimplementasian google classroom pada proses pembelajaran pada kategori mudah, dan $70,27 \%$ siswa memahami cara pengimplementasian google classroom pada proses pembelajaran setelah dijelaskan oleh guru. Secara umum, siswa memiliki persepsi yang baik terhadap pengimplementasian google classroom pada pembelajaran selama masa pandemi Covid-19. Kendati demikian, siswa mengindikasikan bahwa sistem pembelajaran konvensional (tatap muka) masih sangat dibutuhkan melalui interpretasi data dari beberapa indikator penelitian.

\section{SARAN}

Penting dilakukan analisis persepsi siswa secara berkala agar diperoleh interpretasi perkembangan dan perubahan persepsi siswa terhadap google classroom berdasarkan mingguan atau bulanan. Dengan demikian, kecenderungan perkembangan dan perubahan persepsi siswa dapat diinterpretasi secara menyeluruh dan dapat dipetakan.

\section{DAFTAR PUSTAKA}

Al-Maroof, R. A. S., \& Al-Emran, M. (2018). Students acceptance of Google classroom: An exploratory study using PLS-SEM approach. International Journal of Emerging Technologies in Learning (iJET), 13(06), 112-123.

Azhar, K. A., \& Iqbal, N. (2018). Effectiveness of Google classroom: Teachers' perceptions. Prizren Social Science Journal, 2(2), 52-66.

Basher, S. A. O. (2017). The impact of Google classroom application on the teaching efficiency of pre-teachers. University of Shagra-Department of Educational Sciences, 1(1), 45-55.

Batita, M. S. R., Wijoyo, S. H., \& Herlambang, A. D. (2013). Analisis Perbandingan Blended Learning berbasis Edmodo dan Google Classroom ditinjau dari Motivasi dan Hasil Belajar Siswa. Jurnal Pengembangan Teknologi Informasi dan Ilmu Komputer e-ISSN, 2548, 964X.

Cakrawati, L. M. (2017). Students' perceptions on the use of online learning platforms in EFL classroom. English Language Teaching and Technology Journal, 1(1), 22-30.

Haka, N. B., Anggita, L., Anggoro, B. S., \& Hamid, A. (2020). Pengaruh Blended Learning Berbantukan Google Classroom terhadap Keterampilan Berpikir Kreatif dan Kemandirian Belajar Peserta Didik. Edu Sains: Jurnal Pendidikan Sains dan Matematika, 8(1), 1-12.

Hapsari, M. J. (2019). Penggunaan Aplikasi Google Classroom dalam Pembelajaran Matematka Tipe Think Pair Share Di SMKN 3 Banjarmasin. 
Hapsari, S. A., \& Pamungkas, H. (2019). Pemanfaatan Google Classroom sebagai Media Pembelajaran Online di Universitas Dian Nuswantoro. WACANA: Jurnal Ilmiah Ilmu Komunikasi, 18(2), 225-233.

Harefa, N. (2020). LEARNING MANAGEMENT SYSTEM APLIKASI E-LEARNING UNTUK PEMBELAJARAN ONLINE DAN BLENDED.

Harefa, N., \& Purba, L. S. L. (2020, June). Problem solving skills improvement and the impact on students' learning outcomes: learning based e-project. In Journal of Physics: Conference Series (Vol. 1567, No. 2, p. 022038). IOP Publishing.

Harefa, N., \& Suyanti, R. D. (2019, December). Science generic skills of 'chemistry'? prospective teachers: A study on collaborative learning using Exe-media. In Journal of Physics: Conference Series (Vol. 1397, No. 1, p. 012032). IOP Publishing.

Harefa, N., Tafonao, G. S., \& Hidar, S. (2020). Analisis Minat Belajar Kimia Siswa Melalui Pembelajaran Berbasis Multimedia. Paedagoria: Jurnal Kajian, Penelitian dan Pengembangan Kependidikan, 11(2), 81-86.

Heggart, K. R., \& Yoo, J. (2018). Getting the most from Google Classroom: A pedagogical framework for tertiary educators. Australian Journal of Teacher Education, 43(3), 9.

Iftakhar, S. (2016). Google classroom: what works and how. Journal of Education and Social Sciences, 3(1), 12-18.

Maesaroh, S. (2019). Penerapan Metode Cooperative Learning dengan Memanfaatan Aplikasi Google Classroom sebagai Upaya Meningkatkan Nilai Karakter Kebaikan Siswa Menengah Pertama. KoPeN: Konferensi Pendidikan Nasional, 1(1), 168-172.

Marhento, G. (2015). Pengaruh Persepsi Siswa Tentang Kompetensi Guru Mengajar dan Motivasi Belajar Terhadap Hasil Belajar IPA. Formatif, 1(3), 234808.

Mohd Shaharanee, I. N., Jamil, J., \& Mohamad Rodzi, S. S. (2016). The application of Google Classroom as a tool for teaching and learning. Journal of Telecommunication, Electronic and Computer Engineering, 8(10), 5-8.

Muslik, A. (2019). Google Classroom sebagai Alternatif Digitalisasi Pembelajaran Matematika di Era Revolusi Industri 4.0. Andragogi: Jurnal Diklat Teknis Pendidikan dan Keagamaan, 7(2), 246-255.

Mustakim, M. (2020). Efektivitas Pembelajaran Daring Menggunakan Media Online Selama Pandemi Covid-19 Pada Mata Pelajaran Matematika. Al asma: Journal of Islamic Education, 2(1), 1-12.

Najichun, M., \& Winarso, W. (2017). Hubungan Persepsi Siswa Tentang Guru Matematika Dengan Hasil Belajar Matematika Siswa [The Relationship Of Students' Perception About The Mathematics Teacher With Students Learning Math Results] (No. 79263). University Library of Munich, Germany.

Nazari, W.A.A.W., Raub, N.A.A., Rama, L., \& Yunus, M.M. (2019). Painting Pictures With Words Via Google Classroom. International Journal of Scientific \& Technology Research, $8(12), 1877-1881$

Nurfalah, E. (2019). Optimalisasi E-Learning berbasis Virtual Class dengan Google Classroom sebagai Media Pembelajaran Fisika. Physics Education Research Journal, 1(1), 46-55.

Portnov-Neeman, Y., \& Barak, M. (2013). Exploring Students' Perceptions about Learning in School: An Activity Theory Based Study. Journal of Education and Learning, 2(3), 9-25.

Remali, A. M., Zulkhepli, F. Z., Selavathy, J., Sanusi, N. S., \& Aris, N. M. Understanding the impact of Students' Perception in Learning toward Academic Performance. 
Putri, G. K., \& Dewi, Y. A. S. (2019). Pengaruh Model Pembelajaran Jarak Jauh Berbasis Google Classroom. AL-FIKRAH: Jurnal Studi Ilmu Pendidikan dan Keislaman, 2(1), 6079.

Riedy, M., Yu, J., \& Zhou, J. (2012). Effect of teaching method on students' perceptions of instructor attributes. Advances in Business Research, 3(1), 141-146.

Saputra, I. D., \& Syafik, A. (2016). Pengaruh Persepsi Terhadap Prestasi Belajar Matematika Siswa Kelas VIII SMP/MTs Se-Kecamatan Gombong Kabupaten Kebumen. EKUIVALEN-Pendidikan Matematika, 21(2).

Septaria, K., Dewanti, B. A., \& Habibbulloh, M. (2019). Implementasi Metode Pembelajaran Spot Capturing Pada Materi Pemanasan Global untuk Meningkatkan Keterampilan Proses Sains. Prisma Sains: Jurnal Pengkajian Ilmu dan Pembelajaran Matematika dan IPA IKIP Mataram, 7(1), 27-37.

Sudarsana, I. K., Putra, I. B. M. A., Astawa, I. N. T., \& Yogantara, I. W. L. (2019, March). The use of Google classroom in the learning process. In Journal of Physics: Conference Series (Vol. 1175, No. 1, p. 012165). IOP Publishing.

Sudibjo, A. (2019). Penggunaan Media Pembelajaran IPA Berbasis Google Classroom pada Materi Alat Optik untuk Meningkatkan Respons Motivasi dan Hasil Belajar Siswa di SMP Negeri 4 Surabaya. Jurnal Education and Development, 7(3), 278-278.

Sugiarto, T. (2020). Peningkatan Hasil Belajar Fisika Melalui Penerapan Media Pembelajaran E-Learning Berbasis Schoology: Studi Kasus di SMAN 1 Karangdowo. Science Education and Application Journal, 2(1), 43-51.

Tumengkol, A. A. (2020). Pengalaman Pembelajaran Berbasis Blended Learning Mata Kuliah Ilmu Alamiah Dasar Menggunakan Google Classroom Pada Mahasiswa Geografi. Jurnal Episentrum, 1(1), 39-43.

Wardana, A. N., \& Hairunnisa, S. E. W. (2018). Pengaruh Persepsi Siswa SMAN 2 Samarinda terhadap Minat dalam Memilih Universitas Mulawarman (Studi pada Siswa Kelas 3).

Zurimi, S. (2019). Penggunaan E-Learning Berbasis Google Classroom Sebagai Media Pendukung dalam Pembelajaran Matematika di MTs Negeri Tulehu. JTRISTE, 6(1), 1-8. 